Ann. rheum. Dis. (1962), 21, 194.

\title{
EFFECT OF FRESH PLASMA INFUSIONS ON THE SENSITIZED SHEEP CELL AGGLUTINATION REACTION IN CASES OF RHEUMATOID DISEASE
}

Halifax, Nova Scotia

The presence of globulins in normal serum which will inhibit the agglutinators present in the serum of most rheumatoid arthritics have been described (Brine, Wedgwood, and Clark, 1958; Franklin, 1960; Gray, 1959; Rantz, Randall, and Kettner, 1959). The relationship of these substances to the agglutinators is still obscure. In the hope of throwing some light on one inter-relationship, that is between the inhibitory activity of plasma vis-à-vis the sensitized sheep cell agglutinator, fresh normal plasma was infused into patients suffering from rheumatoid disease whose serum showed a high Rose-Waaler titre. Subsequent to the infusions, serial Rose-Waaler estimations were made in an attempt to delineate the response in vivo.

\section{Methods and Materials}

The method for determining the Rose-Waaler titre has already been described in detail (Gray, 1959). All the erythrocyte sedimentation rates quoted were estimated by the method of Westergren. The concentration of inhibitory substance in each bottle of plasma used was measured by the addition of aliquots of plasma, dependent on its protein content, to a sensitized sheep cell suspension. This suspension and an ordinary sensitized sheep cell mixture were added to a serially diluted rheumatoid disease serum of known potency. Any difference between the titres was taken as a measure of inhibitory activity. The procedure has been fully discussed elsewhere (Gray, 1959), and in the body of that paper the Plasma Inhibitory Values were indicated by a single figure. This was obtained by dividing the original titre of the rheumatoid serum by the titre resulting after plasma inhibition; for example, if the primary value of the Serum was $1: 128$ and the titre after inhibition $1: 4$, the Plasma Inhibitory Value was 32.

Before plasma was infused into the patients it was felt necessary to determine the duration of the inhibitor in vitro. Three healthy laboratory technicians were bled and each sample of plasma thus obtained was split into six parts. The first samples were titrated immediately for the concentration of inhibitor, and the seconf after storage at $-20^{\circ} \mathrm{C}$. for one week. Subsequent页 the remainder were examined after $2,4,8$, and 12 week storage at the same temperature. The results a shown in Table I (opposite).

It appears that the inhibitory content of plasmes remains fairly stable for at least 3 weeks if it is stored $-20^{\circ} \mathrm{C}$.; however, to be on the safe side, no bottle was used if it was more than 2 weeks old. Five patiengl were treated with fresh plasma infusions. The historg, clinical examination, and laboratory results for each case are given below.

Case 1, a 54-year-old woman, showed hyperextensio而 deformities of the proximal interphalangeal joints and fixed dorsiflexion deformity of the metatarsophalange joints. The V.D. reference laboratory test was negativ. Hb $12 \cdot 7$ g. per cent., W.B.C. 5,800 per c.mm., differentiat normal, serum albumin $4 \cdot 2 \mathrm{~g}$. per cent., serum globuli $2.8 \mathrm{~g}$. per cent., serum electrophoresis pattern norma, latex fixation $1: 320$, erythrocyte sedimentation rate $30 \mathrm{~mm} . / 1 \mathrm{hr}$, Rose-Waaler Control -0 test $1: 64$.

Case 2, a 32-year-old man, had pain on neck movements limitation of range of movement of the shoulders swelling of the fingers with slight limitation of movement swelling of the left knee joint, and a rheumatic nodure of the extensor surface of the right forearm. The erythroj cyte sedimentation rate was $31 \mathrm{~mm} . / 1 \mathrm{hr}$, L.E. celis absent, serum uric acid $4 \cdot 3 \mathrm{mg}$. per cent., Rose-Waale्f Control -0 test $1: 64$.

Case 3, a 41-year-old woman, had stiffness on gettiri⿱ out of bed which eased somewhat after moving aroune and swelling of the hands and wrists; 4 years previousity she had been given Butazolidin and this had caused acute agranulocytosis. She now complained of beim chronically tired and her appetite was poor. Sma rheumatoid nodules could be felt over each olecranom bursa. The spleen was palpable. The elbows lack 
TABLE I

RESULTS IN NORMAL SERA

\begin{tabular}{|c|c|c|c|c|c|c|c|}
\hline \multirow{2}{*}{$\begin{array}{c}\text { Time } \\
\text { Interval } \\
\text { (wks) }\end{array}$} & \multirow[b]{2}{*}{ Specimen } & \multirow{2}{*}{$\begin{array}{l}\text { Serum Protein } \\
\text { (g. per cent.) }\end{array}$} & \multicolumn{3}{|c|}{ Rose-Waaler Titre } & \multirow{2}{*}{$\begin{array}{l}\text { Plasma added to } \\
\text { Sensitized Sheep } \\
\text { Cell Suspension } \\
\text { (ml. per ml.) }\end{array}$} & \multirow{2}{*}{$\begin{array}{l}\text { Rose-Waaler Titre of } \\
\text { Rheumatoid Sera } \\
\text { after Addition } \\
\text { of Plasma }\end{array}$} \\
\hline & & & $\begin{array}{r}\text { Plasma } \\
\text { Con }\end{array}$ & $\begin{array}{l}\text { der Test } \\
\text { Test }\end{array}$ & $\begin{array}{c}\text { Rheumatoid } \\
\text { Sera }\end{array}$ & & \\
\hline 0 & $\begin{array}{l}\mathbf{T} \\
\mathbf{B} \\
\mathbf{M}\end{array}$ & $\begin{array}{l}8 \cdot 4 \\
7 \cdot 9 \\
7 \cdot 6\end{array}$ & $\begin{array}{l}\mathbf{0} \\
\mathbf{0} \\
\mathbf{0}\end{array}$ & $\begin{array}{l}1: 2 \\
0 \\
0\end{array}$ & $\begin{array}{l}1: 256 \\
1: 256 \\
1: 256\end{array}$ & $\begin{array}{l}0 \cdot 013 \\
0 \cdot 015 \\
0 \cdot 017\end{array}$ & $\begin{array}{l:l}1 & : 2 \\
1 & : 2 \\
1 & : 4\end{array}$ \\
\hline 1 & $\begin{array}{l}\mathbf{T} \\
\mathbf{B} \\
\mathbf{M}\end{array}$ & $\begin{array}{l}7 \cdot 6 \\
7 \cdot 1 \\
6 \cdot 8\end{array}$ & $\begin{array}{l}\mathbf{0} \\
\mathbf{0} \\
\mathbf{0}\end{array}$ & $\begin{array}{l}\mathbf{0} \\
\mathbf{0} \\
\mathbf{0}\end{array}$ & $\begin{array}{l}1: 256 \\
1: 256 \\
1: 256\end{array}$ & $\begin{array}{l}0 \cdot 017 \\
0 \cdot 020 \\
0 \cdot 022\end{array}$ & $\begin{array}{l}0 \\
1: 2 \\
1: 2\end{array}$ \\
\hline 2 & $\begin{array}{l}\mathbf{T} \\
\mathbf{B} \\
\mathbf{M}\end{array}$ & $\begin{array}{l}7 \cdot 6 \\
7 \cdot 1 \\
6 \cdot 8\end{array}$ & $\begin{array}{l}1: 2 \\
0 \\
0\end{array}$ & $\begin{array}{l}1: 2 \\
0 \\
1: 2\end{array}$ & $\begin{array}{l}1: 128 \\
1: 128 \\
1: 128\end{array}$ & $\begin{array}{l}0 \cdot 017 \\
0 \cdot 020 \\
0 \cdot 022\end{array}$ & $\begin{array}{l:l}1 & : 4 \\
1 & : 2 \\
1 & : 2\end{array}$ \\
\hline 4 & $\begin{array}{l}\mathbf{T} \\
\mathbf{B} \\
\mathbf{M}\end{array}$ & $\begin{array}{l}7 \cdot 5 \\
7 \cdot 1 \\
6 \cdot 5\end{array}$ & $\begin{array}{l}1: 2 \\
0 \\
0\end{array}$ & $\begin{array}{l}1: 2 \\
0 \\
1: 2\end{array}$ & $\begin{array}{l}1: 64 \\
1: 64 \\
1: 64\end{array}$ & $\begin{array}{l}0.017 \\
0.020 \\
0.023\end{array}$ & $\begin{array}{l:l}1 & : 4 \\
1 & : 4 \\
1 & : 2\end{array}$ \\
\hline 8 & $\begin{array}{l}\mathbf{T} \\
\mathbf{B} \\
\mathbf{M}\end{array}$ & $\begin{array}{l}7 \cdot 5 \\
7 \cdot 1 \\
6 \cdot 5\end{array}$ & $\begin{array}{l:l}1: 2 \\
0 \\
1: 2\end{array}$ & $\begin{array}{l:l}1 & : 4 \\
1 & : 2 \\
1 & : 2\end{array}$ & $\begin{array}{l}1: 64 \\
1: 64 \\
1: 64\end{array}$ & $\begin{array}{l}0.017 \\
0.020 \\
0.023\end{array}$ & $\begin{array}{l:l}1 & : 8 \\
1 & : 4 \\
1 & : 4\end{array}$ \\
\hline 12 & $\begin{array}{l}\mathbf{T} \\
\mathbf{B} \\
\mathbf{M}\end{array}$ & $\begin{array}{l}7 \cdot 5 \\
7 \cdot 1 \\
6 \cdot 5\end{array}$ & $\begin{array}{l}\mathbf{0} \\
\mathbf{0} \\
\mathbf{0}\end{array}$ & $\begin{array}{l}1: 32 \\
1: 16 \\
1: 16\end{array}$ & $\begin{array}{l}1: 128 \\
1: 128 \\
1: 128\end{array}$ & $\begin{array}{l}0 \cdot 017 \\
0 \cdot 020 \\
0 \cdot 023\end{array}$ & $\begin{array}{l}1: 128 \\
1: 128 \\
1: 128\end{array}$ \\
\hline
\end{tabular}

a few degrees of extension and were painful when forced, there was limitation of wrist movement and both wrists were tender, the proximal and terminal interphalangeal joints were swollen and tender, and the same change was present in the toe joints. W.B.C. 3,200 with 52 per cent. neutrophils, L.E. cells absent, erythrocyte sedimentation rate $90 \mathrm{~mm}$./ $1 \mathrm{hr}$, Rose-Waaler Control -0 test $1: 128$. This patient was considered to be a case of Felty's syndrome.

Case 4, a 47-year-old woman, had experienced the onset of rheumatism in January, 1959, with soreness in the ankles with some swelling, and the hands, arms, and shoulders later became involved. Morning stiffness was present. When she was seen in January, 1960, there was tenderness of the wrists and left metacarpophalangeal joints, crepitus of the knee joints, and tenderness of the left ankle. The affected joints were slightly swollen. The V.D. reference laboratory test was negative, $\mathrm{Hb}$ 13.6 g. per cent., haematocrit 46 per cent., W.B.C. 14,150 with a neutrophil leukocytosis, erythrocyte sedimentation rate $40 \mathrm{~mm} . / 1 \mathrm{hr}$, urine analysis negative, latex-fixation test positive, L.E. cells absent, serum albumin $3.8 \mathrm{~g}$. per cent., serum globulin $2.5 \mathrm{~g}$. per cent. Electrophoresis showed a marked increase of $\alpha_{2}$ and gamma globulin.

Case 5, a 47-year-old man, had first experienced symptoms in 1958, with pain, swelling, and stiffness of the fingers and shoulders. When seen in February, 1960, he had a severe degree of rheumatoid arthritis sparing only the spine, sacro-iliac joints and hip joints. Urine analysis was negative, $\mathrm{Hb} 10.4 \mathrm{~g}$. per cent., W.B.C. 7,200, normal differential. V.D. reference laboratory test negative, L.E. cells absent, latex-fixation test $1: 640$, serum albumin $3 \cdot 6 \mathrm{~g}$. per cent., serum globulin $2 \cdot 3 \mathrm{~g}$. per cent. ( $\alpha_{2} 18 \cdot 1$ per cent., gamma $21 \cdot 7$ per cent.), Rose-Waaler Control -0 test $1: 64$, erythrocyte sedimentation rate $130 \mathrm{~mm} . / 1 \mathrm{hr}$.

\section{Results}

The effect of multiple fresh plasma infusions on the Rose-Waaler and erythrocyte sedimentation rate in all five cases is shown in Table II (overleaf).

In Case 4 the plasma infusions had to be stopped because of a focal antigen-antibody response. In February, 1960, an intermediate purified protein derivative was done on the patient's right forearm; it was noted to be strongly positive by February 20, and on March 3, during the administration of the first bottle of plasma, a large bulla formed at the site of the previously positive tuberculin test; this subsided the following day, but the ankle joints became markedly swollen by the same evening and remained acutely uncomfortable for nearly a week.

The Rose-Waaler response to the plasma infusions was marked in all five cases, the titres during some period of the trial dropping to normal, and in some cases to very low normal levels. Judging the best results by the duration of a very low titre, it appears that the optimum effect is produced by infusing two bottles of high inhibitor value plasma at about 3-day intervals as exemplified by Case 3 . In Case 1 the first two bottles given were of poor quality and subsequent infusions were inadequate in volume, and the same criticism is applicable to Case 2. In Case 5 the plasma was potent and the volume should have been adequate, but the spacing between 
infusions was too prolonged. A completely unexpected finding was the alteration in the erythrocyte sedimentation rate which was apparently induced by the infusions. In four cases the erythrocyte sedimentation rate decreased significantly: Case 1 from 30 to 18 , Case 2 from 23 to 15 , Case 3 from 90 to 33, and Case 5 from 129 to 108 . This change did not immediately follow the downward movement of the Rose-Waaler, but appeared on the whole to be more closely related to the length of time the Rose-Waaler titre was kept low.

TABLE II

EFFECT OF PLASMA INFUSION IN FIVE CASES

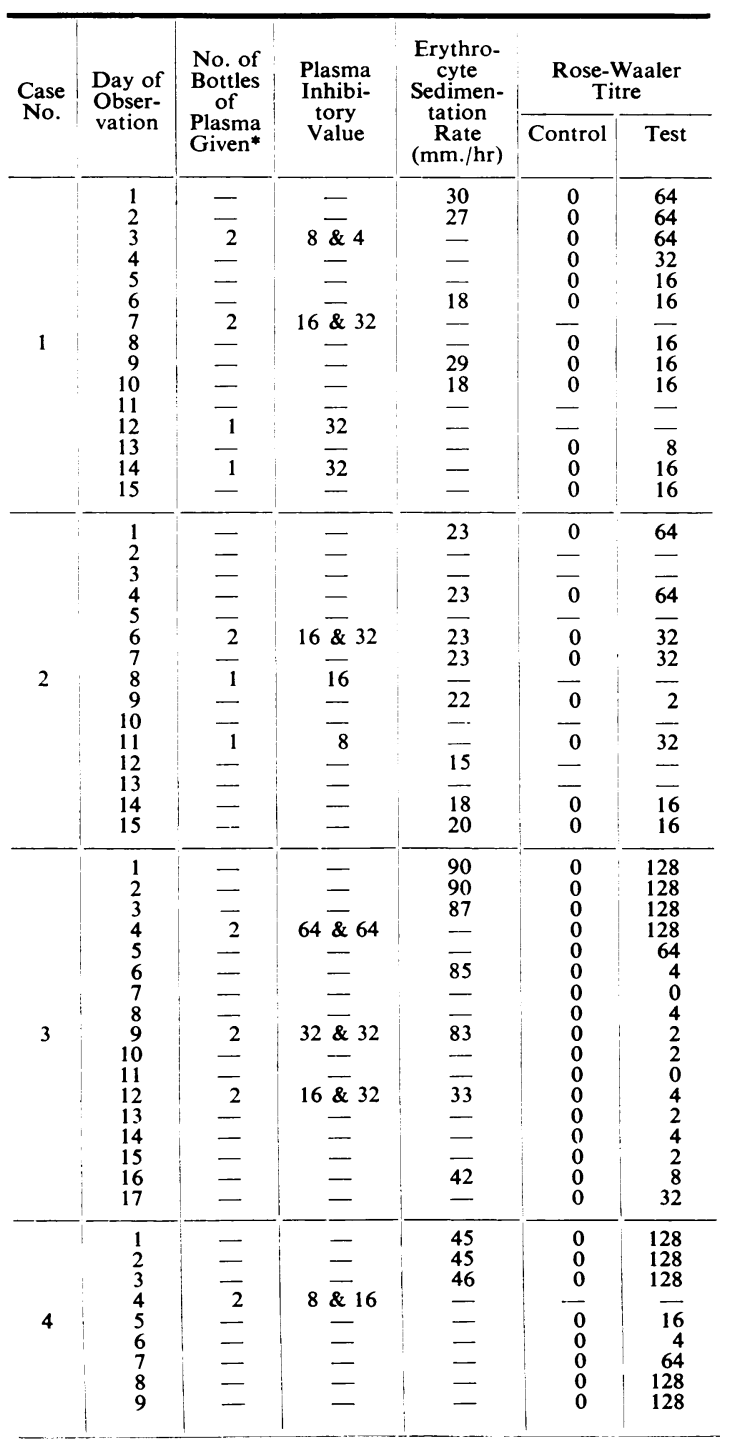

TABLE II continued

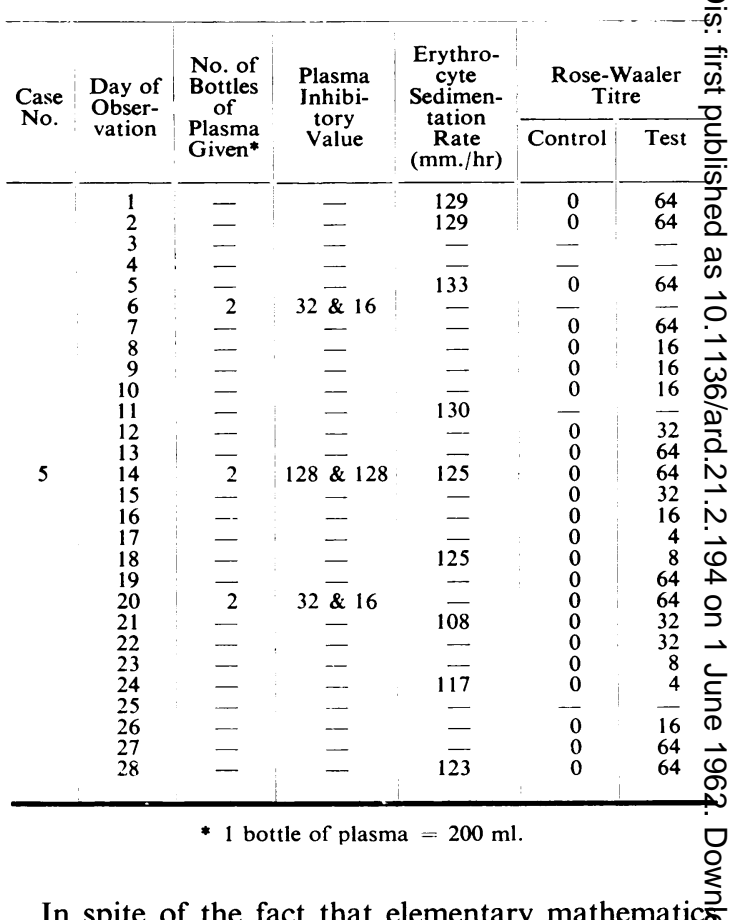
indicated that haemodilution was unlikely to be responsible factor in depressing both Rose-Waale\& and erythrocyte sedimentation rate in the plasmit treated cases, it was felt that this possibility shoul 9 be put to experiment. Three further cases of rheumatoid disease of a similar calibre were there? fore subjected to the same trial, but with the subs stitution of 5 per cent. glucose in normal saline for plasma. These three cases are summarize below:

Case 6, a 49-year-old man, had a 6-year history of polyarthritis. There was limitation of movement in the shoulder and hip joints, tenderness and swelling in both wrists, and some limitation of movement in the left ank joint. Rheumatoid nodules were present over both the olecranon and greater trochanteric regions. Urinos normal, $\mathrm{Hb} 10 \cdot 9$ g. per cent., W.B.C. total and differeno tial normal, V.D. reference laboratory test negative L.E. cells absent, blood uric acid $3 \cdot 2 \mathrm{mg}$. per cenţ, plasma protein $7.5 \mathrm{~g}$. total (albumin $4.5 \mathrm{~g}$. per cento globulin $3 \mathrm{~g}$. per cent.). Electrophoresis of plasma protein, albumin 38 per cent., globulin alpha-1 $7 \cdot 2$ pe्ष cent., alpha-2 13.7 per cent., beta 12.7 per cent., gammen 28.5 per cent. Erythrocyte sedimentation rate $80 \mathrm{~mm}-\mathrm{t}$ $1 \mathrm{hr}$, Rose-Waaler Control -0 test $1: 128$.

Case 7, a 47-year-old man, had never been free of arthritic symptoms for more than 3 months at a time i⿺ the last 18 years. There was spindle-shaped deformity of 
all proximal interphalangeal joints, ulnar deviation, restricted shoulder movements, and swelling of the metatarso- and interphalangeal joints of the feet. Hb $11 \cdot 2 \mathrm{~g}$. per cent., W.B.C. normal. Urine analysis negative, uric acid $3.2 \mathrm{mg}$. per cent., plasma protein $7 \cdot 1 \mathrm{~g}$. per cent., albumin $4 \cdot 5 \mathrm{~g}$. per cent., globulin $2 \cdot 6 \mathrm{~g}$. per cent. Plasma electrophoretic pattern albumin $43 \cdot 5$ per cent., globulin alpha-1 $6 \cdot 5$ per cent., alpha-2 $14 \cdot 1$ per cent., beta $13 \cdot 1$ per cent., gamma $22 \cdot 8$ per cent. Latexfixation $1: 1,280$, Rose-Waaler control -0 test $1: 128$, erythrocyte sedimentation rate $90 \mathrm{~mm} . / 1 \mathrm{hr}$.

Case 8, a 69-year-old woman, had had stiffness and pain and swelling in the hands, wrists, elbows, and shoulders for the last 18 months. There was fusiform swelling of the proximal and distal interphalangeal joints of both hands. The shoulder joints had a restricted range of movement. The knee joints were swollen and painful on movement. Hb 10.6 g. per cent., W.B.C. normal, L.E. cells absent, urine analysis negative, V.D. reference laboratory test negative, latex-fixation $1: 640$, uric acid $5 \cdot 1 \mathrm{mg}$. per cent. Plasma proteins 6.8 g. per cent., albumin 3.6 g. per cent., globulin $3 \cdot 2$ g. per cent. (alpha-1 7 per cent., alpha-2 $19 \cdot 6$ per cent., beta $17 \cdot 6$ per cent., gamma $26 \cdot 1$ per cent.).

\section{Results}

The effects of the glucose-saline infusions on the Rose-Waaler and erythrocyte sedimentation rate in Cases 6 to 8 are shown in Table III. The infusions had no influence on either test in these controls.

The time taken to infuse either plasma or glucose saline was about the same, that is from 75 to 90 min. per bottle.

\section{Discussion}

The effect of the intravenous plasma infusions on the Rose-Waaler reaction was the same in all five patients, by the third to fourth day it had dropped to normal or near normal levels and in Case 3 it was maintained at a "normal" level for 9 days by multiple infusions at 3-day intervals. Escape from the donated plasma inhibitor, however, was extremely rapid, for on the 5th to 6 th day after infusion the titres had risen to approximately the pre-treatment levels.

The timing of this phenomenon suggests that the reaction is not that of a colloid stabilizer but rather the true combining of an inhibitor with factor to form a serologically inert substance. A stabilizer could be expected to depress the titre shortly after an infusion and, as the "foreign" protein was destroyed, to return at a steady rate to its primary value. In fact the reverse occurred, in that the depression of titre took at least 3 days to reach its maximum and the effect was extremely transient, lasting not more than 24 to $48 \mathrm{hrs}$. This would
TABLE III

\begin{tabular}{|c|c|c|c|c|c|}
\hline \multirow[t]{2}{*}{$\begin{array}{l}\text { Case } \\
\text { No }\end{array}$} & \multirow[t]{2}{*}{$\begin{array}{l}\text { Day of } \\
\text { Obser- } \\
\text { vation }\end{array}$} & \multirow{2}{*}{$\begin{array}{l}\text { No. of } \\
\text { Bottles of } \\
\text { Glucose- } \\
\text { saline } \\
\text { Given* }\end{array}$} & \multirow{2}{*}{$\begin{array}{c}\text { Erythrocyte } \\
\text { Sedimentation } \\
\text { Rate } \\
(\mathrm{mm} \cdot / \mathrm{hr})\end{array}$} & \multicolumn{2}{|c|}{$\begin{array}{c}\text { Rose-Waaler } \\
\text { Titre }\end{array}$} \\
\hline & & & & Control & Test \\
\hline 6 & $\begin{array}{r}1 \\
2 \\
3 \\
4 \\
5 \\
6 \\
7 \\
8 \\
9 \\
10 \\
11 \\
12 \\
13 \\
14 \\
15 \\
16\end{array}$ & $\begin{array}{l}\bar{z} \\
\frac{2}{1} \\
\bar{z} \\
= \\
= \\
= \\
= \\
=\end{array}$ & $\begin{array}{l}76 \\
77 \\
80 \\
\frac{79}{82} \\
\frac{1}{82} \\
83 \\
86 \\
88 \\
83 \\
-\end{array}$ & $\begin{array}{l}0 \\
0 \\
0 \\
0 \\
0 \\
0 \\
0 \\
0 \\
0 \\
0 \\
-\end{array}$ & $\begin{array}{l}128 \\
128 \\
128 \\
128 \\
\frac{128}{128} \\
\frac{128}{128} \\
128 \\
128 \\
\frac{128}{-} \\
-\end{array}$ \\
\hline 7 & $\begin{array}{r}1 \\
2 \\
3 \\
4 \\
5 \\
6 \\
7 \\
8 \\
9 \\
10 \\
11 \\
12 \\
13 \\
14 \\
15 \\
16\end{array}$ & $\begin{array}{l}\bar{z} \\
\overline{2} \\
\overline{2} \\
\overline{2} \\
= \\
= \\
= \\
=\end{array}$ & $\begin{array}{c}95 \\
97 \\
98 \\
98 \\
98 \\
97 \\
\overline{-} \\
101 \\
\overline{95} \\
93 \\
92 \\
92\end{array}$ & $\begin{array}{c}0 \\
0 \\
0 \\
0 \\
0 \\
0 \\
- \\
0 \\
0 \\
0 \\
0 \\
0\end{array}$ & $\begin{array}{r}128 \\
128 \\
1 \overline{128} \\
128 \\
\overline{128} \\
128 \\
\overline{-} \\
128 \\
1 \overline{128} \\
64 \\
128 \\
128\end{array}$ \\
\hline 8 & $\begin{array}{r}1 \\
2 \\
3 \\
4 \\
5 \\
6 \\
7 \\
8 \\
9 \\
10 \\
11 \\
12 \\
13 \\
14 \\
15 \\
16\end{array}$ & $\begin{array}{l}\bar{Z} \\
\frac{2}{2} \\
= \\
= \\
= \\
= \\
= \\
=\end{array}$ & $\begin{array}{l}86 \\
90 \\
90 \\
85 \\
94 \\
90 \\
90 \\
95 \\
96 \\
93 \\
97 \\
91 \\
90\end{array}$ & $\begin{array}{c}0 \\
0 \\
0 \\
0 \\
0 \\
0 \\
0 \\
0 \\
0 \\
0 \\
0 \\
0 \\
0\end{array}$ & $\begin{array}{l}128 \\
128 \\
128 \\
128 \\
128 \\
128 \\
\overline{128} \\
128 \\
128 \\
128 \\
128 \\
128 \\
128\end{array}$ \\
\hline
\end{tabular}

$* 1$ bottle $=500 \mathrm{ml} .5$ per cent. glucose in normal saline.

seem to indicate a progressive union between inhibitor and factor which lasts until the donated inhibitor has been used up; at this point the continued production of factor rapidly returns the titre value to its previous height.

The tendency of the Rose-Waaler titre to revert to a pretreatment level in spite of the transient alteration induced by fresh plasma and the fact that, during the maximum effect given by the donated inhibitor, a pathological serum may be made to mimic a normal serum, suggest that agglutinator is produced at a steady pace, and that the primary defect in rheumatoid disease is a loss either partial or complete of inhibitor synthesis.

In four of the five cases the erythrocyte sedimentation rate was influenced by the plasma infusions. 
The drop in the rate varied from case to case and not always parallel in time to the decline in the Rose-Waaler titre. It is tempting to consider this reaction as physiological and due to a possible decrease in the positive electrical charge in the patient's plasma coupled with a lowcring of either fibrinogen or globulin or both; if this were the case, however, the change in the erythrocyte sedimentation rate should occur promptly after each infusion and should depend on its size, but this was not so, and inspection of the data indicates that on the whole the depression of the erythrocyte sedimentation rate was related to a persistence in the reduction of the Rose-Waaler titre rather than to anything else.

No attempt was made to assess the therapeutic value of the fresh plasma infusions, nor was established routine treatment for these cases altered in any way during the course of the experiments. Our primary purpose was to establish the possibility of influencing a high titre by donating inhibitor. However, if inhibitor is to be considered as a possible therapeutic agent, it seems obvious that it must be isolated in a pure and concentrated form which can be administered in sufficient dosage to keep the agglutinating factor inactivated for what is at present an unknown length of time.

\section{Summary}

Five patients with rheumatoid disease with high Rose-Waaler titres were given multiple infusions of fresh plasma. This procedure was followed by a significant fall in the titre to normal or near normal levels. The effect was transient. Coincidentally the erythrocyte sedimentation rate declined with the reversion of the Rose-Waaler titre to normal. This also was a transient phenomenon.

The therapeutic value of fresh plasma as a form of treatment in rheumatoid disease was not assessed.
I am deeply indebted to Dr. J. F. Woodbury for access] to the patients who took part in this trial and to Drẹ. H. C. Read for supplies of fresh plasma.

\section{REFERENCES}

Brine, K. L., Wedgwood, R. J., and Clark, W. S. (1958) Arthr. and Rheum., 1, 230.

Franklin, E. C. (1960). Ibid., 4, 326.

Gray, J. D. (1959). J. Immunol., 83, 1.

Rantz, L. A., Randall, E., and Kettner, D. (1959) $\vec{\circ}$ Arthr. and Rheum., 2, 104.

Effet d'infusions de plasma frais sur la réaction d'agglup tination des érythrocytes sensibilisés de mouton dans de ֶ̧ cas de maladie rhumatismale

\section{RÉSUMÉ}

Cinq sujets atteints de maladie rhumatismale et ayan des titres élevés de la réaction de Rose-Waaler reçurent des infusions répétées de plasma frais. Ce procédé fub suivi d'une chute appréciable de ce titre, qui atteint desvaleurs normales ou presque normales. Cet effet fufephémère. La chute du titre de la réaction de Roses Waaler fut accompagnée, pour une période aussi courte par une diminution de la vélocité de sédimentatiorèo globulaire.

Le plasma frais comme moyen thérapeutique dans la maladie rhumatismale ne fut pas évalué.

Efecto de infusiones de plasma fresco sobre la reacción d aglutinación de los eritrocitos sensibilizados de carnerō en casos de enfermedad reumatoide

\section{SUMARIO}

Cinco sujetos con enfermedad reumatoide y coß altos valores en la reacción de Rose-Waaler recibiero? repetidas infusiones de plasma fresco. Este procedep? fué seguido por un descenso apreciable de dichos valores hasta cifras normales o casi normales. efecto fué pasajero. Al mismo tiempo la velocidad dê sedimentación eritrocitaria disminuyó, juntamente cọ normalización de la reacción de Rose-Waaler. Estetambién, fué un efecto pasajero.

El valor del plasma fresco como una forma de trata miento en la enfermedad reumatoide no fué estimado. 